\title{
Cyanogenesis in Turnera ulmifolia L. (Turneraceae). I. Phenotypic distribution and genetic variation for cyanogenesis on Jamaica
}

\author{
P. J. SCHAPPERT* \& J. S. SHORE \\ Department of Biology, York University, 4700 Keele Street, North York, Ontario, Canada M3J IP3
}

\begin{abstract}
A survey of 39 discrete populations of Turnera ulmifolia on Jamaica reveals extensive phenotypic variation for cyanogenesis among populations. The variation is quantitative and appears to be the result of differences in the quantity of cyanogenic glycoside possessed by plants. Controlled crosses and greenhouse studies show that there is a genetic basis to the variation with between-family variance accounting for more than 80 per cent of the variation in one population. Seedlings have significantly higher levels of cyanogenesis than mature plants in largely acyanogenic populations but this age-specific variation is absent in predominately cyanogenic populations. We identify potential selective agents that might account for the spatial distribution of cyanogenesis on the island and discuss the geographical pattern with respect to population elevation, precipitation regimes and the distribution of herbivores. This investigation provides the first detailed study of the ecological genetics of cyanogenesis in natural populations of a tropical plant.
\end{abstract}

Keywords: cyanogenesis, developmental variation, ecological genetics, natural selection, Turnera ulmifolia

\section{Introduction}

Cyanogenesis is perhaps the most thoroughly studied example of chemical defence in plants. Cyanogenesis, the ability of plants to liberate hydrogen cyanide upon damage to tissues, is very widespread and has been documented in more than 3000 species of ferns, gymnosperms, and angiosperms (Poulton, 1990). The disruption of tissues (by herbivores or mechanically), in the vast majority of species, brings a cyanogenic glycoside in contact with a $\beta$-glycosidase enzyme that hydrolyses the molecule, liberating a sugar and a cyanohydrin. The cyanohydrin subsequently dissociates, either spontaneously or catalysed by an $\alpha$ hydroxynitrile lyase, to $\mathrm{HCN}$ and an aldehyde or a ketone (Conn, 1979; Poulton, 1990; Seigler, 1991). Both end-products may be toxic and/or deterrent and act as defensive compounds as might the intact cyanogenic glycoside (Compton \& Jones, 1985; Jones, 1988; Spencer, 1988; Seigler, 1991; but see Scriber, 1978 and Woodhead \& Bernays, 1978).

*Correspondence.
Genetic variation for cyanogenesis has been less commonly documented (Hughes, 1981), but has been well studied in both natural plant populations $(T$. repens, reviewed in Hughes, 1991), as well as in crops such as S. bicolor (Nass, 1972; Eck et al., 1975). For T. repens, variation in cyanogenesis is controlled by polymorphisms at two gene loci and may be similarly controlled in Lotus corniculatus (Dawson, 1941; Jones, 1977). One locus determines the presence or absence of a cyanogenic glycoside while the second controls the presence or absence of a $\beta$-glycosidase. More recent studies of $T$. repens have revealed that there are different functional alleles coding for the cyanogenic glycoside that result in the production of different amounts of the chemical (Hughes et al., 1984). In S. bicolor, cyanogenesis appears to be a polygenic trait (Nass, 1972; Eck et al., 1975). Polymorphism for cyanogenesis has also been reported in natural populations of the bracken fern, Pteridium aquilinum (Cooper-Driver \& Swain, 1976). There are also developmental and environmental effects on the expression of cyanogenesis in T. repens (Till, 1987) and L. corniculatus (Ellis et al., 1977a), as well as differences in expression 
between diploid and tetraploid $L$. corniculatus growing in common environments (Urbanska, 1982; Blaise et al., 1991). In addition, the expression of cyanogenesis may be modified if varying amounts of two or more different cyanogenic glycosides are present (Daday, 1965; Spencer et al., 1985; Olafsdottir et al., 1990) and the specificity of $\beta$-glycosidases varies (Hösel and Conn, 1982).

The cyanogenesis polymorphisms in Lotus corniculatus and Trifolium repens have been exploited by a number of workers, especially D. A. Jones and coworkers (Jones, 1962, 1966, 1971, reviewed in 1973, 1981 and 1988; Jones et al., 1978; Ellis et al., 1977a,b,c; Compton \& Jones, 1985) as well as others (Daday, 1954a,b, 1965; Bishop \& Korn, 1969; Angseesing \& Angseesing, 1973; Abbott, 1977; Scriber, 1978; Dritschilo et al., 1979; Ennos, 1981; Dirzo \& Harper, 1982a, b; Horrill \& Richards, 1986; Blaise et al., 1991) to address questions of chemical defence and to demonstrate the action of natural selection in wild plant populations. Similar studies have been carried out for bracken fern (Cooper-Driver \& Swain, 1976; Cooper-Driver et al., 1977; Schreiner et al., 1984). In addition, polymorphism for cyanogenesis provides a system for the study of 'coevolutionary ecological genetics' (Jones et al., 1978; Dirzo \& Harper, 1982a; Burgess \& Ennos, 1987).

The data on the effects of cyanogenesis generally reveal that some herbivores selectively consume acyanogenic plants (Jones, 1962, 1966; Cooper-Driver \& Swain, 1976; Dritschilo et al., 1979; Dirzo \& Harper, 1982a; Compton \& Jones, 1985; Horrill \& Richards, 1986; Burgess \& Ennos, 1987; reviewed by Nahrstedt, 1985 and Kakes, 1990; but see Scriber, 1978; Hruska, 1988). In some environments, cyanogenic plants are apparently selected against by abiotic agents such as frost or low temperatures (Daday, 1954a,b, 1965; Ellis et al., 1977a; Foulds \& Young, 1977; Dirzo \& Harper, 1982b) or low moisture stress (Foulds \& Grime, 1972; Abbott, 1977; but see Foulds, 1977) and there may be other costs associated with cyanogenesis (Dirzo \& Harper, 1982b; Kakes, 1989; Briggs \& Schultz, 1990).

We have initiated research on the ecological genetics of cyanogenesis in a tropical species, Turnera ulmifolia . Turnera ulmifolia is a weedy perennial common to roadsides, and disturbed and coastal scrub habitats throughout the Neotropics. The plants found on the island of Jamaica are typically low shrubs that are selfcompatible, partially inbreeding, and hexaploid (Barrett \& Shore, 1987; Belaoussoff \& Shore, 1995). Importantly, numerous species in the Turneraceae have been investigated and are known to be cyanogenic and to possess cyclopentenoid cyanogenic glycosides (Spencer \& Seigler, 1980, 1981; Spencer et al., 1985;
Olafsdottir et al., 1990; Shore \& Obrist, 1992). The Turneraceae are thought to be closely allied to the Passifloraceae (Takhtajan, 1969), a family known to possess a chemically similar but more diverse array of cyclopentenoid cyanogenic glycosides (Saupe, 1981; Spencer, 1988). Limited studies by Spencer et al. (1985), Olafsdottir et al. (1990) and Shore \& Obrist (1992) all noted variation in cyanogenesis among plants of T. ulmifolia.

In this paper we (1) document wide phenotypic variation for cyanogenesis among natural populations of T. ulmifolia on Jamaica, (2) assess the nature of chemical variation in the plant showing that the variation appears to be the result of variability in the quantity of cyanogenic glycoside possessed by plants, and (3) use controlled crosses and greenhouse studies to show that there is a genetic basis to the variation in cyanogenesis observed among Jamaican populations. We also show that (4) there is age-specific variation for the trait, at least in some populations, and (5) identify potential selective agents that might account for the spatial distribution of cyanogenesis on Jamaica.

\section{Materials and methods}

\section{Quantification of cyanogenesis}

We commonly used the methods detailed in Shore \& Obrist (1992) to measure cyanogenesis in both the field and lab. This involved a chemical test with sodium picrate paper (see Brinker \& Seigler, 1989 for standard protocols; Seigler, 1991) that can be easily carried out in the field. Unless indicated otherwise (see below), we measured cyanogenesis for each plant by taking six 0.6 $\mathrm{cm}$ leaf discs (total approximately $8.0 \mathrm{mg}$ dry weight), using a hole punch, from a leaf bearing either a mature flower or the most mature flower bud (to control for developmental variation; Shore \& Obrist, 1992). Note that flowers of $T$. ulmifolia are short-lived $(4-8 \mathrm{~h})$ and are borne singly on the petiole of the subtending leaf. The leaf discs were placed in a $1.5 \mathrm{~mL}$ microcentrifuge tube to which we added approximately $7 \mu \mathrm{L}$ of chloroform and the leaf discs were crushed.

A piece of picrate paper (approx. $9 \mathrm{~mm} \times 13 \mathrm{~mm}$ ) was quickly placed at the top of the tube which was then sealed. Tubes were left for $24 \mathrm{~h}$ for a reaction to occur. The picrate paper changes from yellow to an orange, rust or a dark brown colour depending on the amount of $\mathrm{HCN}$ released. Previous work had verified that $\mathrm{HCN}$ liberation was responsible for the reaction of the picrate paper (Shore \& Obrist, 1992). For field samples in Jamaica, the tubes were left at room temperature $\left(25^{\circ}-30^{\circ} \mathrm{C}\right)$, while in the laboratory they were incubated at $37^{\circ} \mathrm{C}$. After a $24 \mathrm{~h}$ incubation, the microcentrifuge tubes were opened and the picrate 
papers allowed to dry overnight. The reacted picrate, on a single $0.6 \mathrm{~cm}$ disc punched from the test paper, was then eluted in $1 \mathrm{~mL}$ of 50 per cent ethanol and the optical density (OD) of the solution measured at 504 nm using a Spectronic 501 spectrophotometer (Milton Roy). Test papers from field samples were sent to the laboratory in Toronto, Canada for spectrophotometry. There is a linear relationship between $\log (\mathrm{OD})$ and $\log (\mu \mathrm{M} H C N)$ released using this method $\left(r^{2}=0.99\right.$, $P<0.001$; Shore \& Obrist, 1992).

To explore whether acyanogenic plants, or those exhibiting weak cyanogenesis, lack or have reduced levels of the cyanogenic glycoside, we added approximately $7 \mu \mathrm{L}$ of exogenous cyanogenic glycoside to leaf disks that were to be crushed. The cyanogenic glycoside was extracted from highly cyanogenic plants of $T$. ulmifolia by Shore \& Obrist (1992). Plants from three populations (10 or 16 plants per population) were analysed. In each case, the populations exhibited low levels of cyanogenesis. For each plant we used 12 discs from a single leaf for a control cyanogenesis reaction (six discs) and a treatment sample to which glycoside was added (six discs).

For some of our genetic analyses we employed a more precise measure of cyanogenesis, the quantitative method of Lambert et al. (1975), as detailed in Brinker \& Seigler (1989). Briefly, an entire leaf is ground to powder in liquid nitrogen in a $1.5 \mathrm{~mL}$ microcentrifuge tube and placed open into a $20 \mathrm{~mL}$ scintillation vial containing $0.5 \mathrm{~mL}$ of $1 \mathrm{M} \mathrm{NaOH}$. The vial is then sealed and incubated for $24 \mathrm{~h}$ at $37^{\circ} \mathrm{C}$. The $\mathrm{NaOH}$ solution traps the $\mathrm{HCN}$ released from the plant tissue and the amount of cyanide in the $\mathrm{NaOH}$ is then quantified spectrophotometrically after addition of a series of reagents detailed in Brinker \& Seigler (1989). We also prepared solutions to produce a standard curve, following the methods of Brinker \& Seigler (1989). After incubation, the crushed plant tissue in each microcentrifuge tube is dried to constant weight in a drying oven at $65^{\circ} \mathrm{C}$ so that $\mu \mathrm{g} \mathrm{HCN}$ liberated per gram dry weight of tissue can be calculated. Preliminary analyses revealed that it was not necessary to add exogenous $\beta$-glycosidase to the samples as all detectable $\mathrm{HCN}$ is driven out of the tissue after $24 \mathrm{~h}$ of incubation.

\section{Sampling of natural plant populations}

In the summers of 1990 and 1991 we sampled populations of T. ulmifolia when they were encountered. For small populations, we sampled every plant in the population while for populations composed of more than 100 plants we took a random or in some cases an arbitrary sample of plants. Cyanogenesis tests were either performed immediately at the site, or more commonly, a single flowering shoot $(15-20 \mathrm{~cm}$ in length) was sampled from each plant and these were placed in plastic bags, and kept cool until they could be processed later that day. We restricted our sampling to plants that were flowering, typically to plants that were at least $50 \mathrm{~cm}$ in height (hereafter referred to as adult plants). Seedlings were not commonly observed in populations, but we were able to find and assay seedlings in 16 of the 39 populations surveyed. These were identified as plants that had no flowers, buds or fruit and were less than $20 \mathrm{~cm}$ in height. In addition, we chose plants that had a very narrow stem diameter, to ensure they did not represent adult plants that had been previously damaged or cut back. As the seedlings possessed no flowers or buds we chose a leaf for cyanogenesis that was approximately the same size and/or at the same position on the shoot as those chosen for adult plants.

To construct a map of the phenotypic distributions of cyanogenesis on Jamaica we divided the observations into five classes (0-4). Our zero class consisted of plants with an OD less then 0.02. Based on our observations of picrate colour change and experimental error we chose this level as indicating lack of cyanogenesis. Some plants in this range may be cyanogenic and are misclassified because there is little $\mathrm{HCN}$ released and it is below the detection limit of the method used. In any case, these plants are at the low end of the cyanogenesis spectrum. A total of 41.2 per cent ( 650 plants) of all adult plants sampled fell into this category. We are confident that the remaining 58.8 per cent of plants are cyanogenic. We defined the remaining categories (1-4) by placing an equal percentage ( 14.7 per cent) of plants into each category (in essence, the remaining plants were ranked and divided into quartiles).

For each population, we were able to determine latitude, longitude, and approximate elevation from 1:50000 topographic maps, using the midpoint between contour lines to estimate elevation data. Precipitation data were obtained from the literature (JIS, 1967). This source provides 91-year means for monthly precipitation for a large number of sites. The distance from surveyed plant populations to precipitation source records never exceeded $11.2 \mathrm{~km}$ (straight line distance); in most cases, plant populations and precipitation records coincided (mean $\pm S D$ distance: $2.35 \pm 3.05 \mathrm{~km}$ ). Most populations occupied discrete areas. At Kinloss, however, plants were scattered in small aggregations along the road for about $10 \mathrm{~km}$. To examine whether there was variation for cyanogenesis on a fine spatial scale, plants were sampled at six locations along the $10.3 \mathrm{~km}$ transect, roughly every 2 $\mathrm{km}$.

(c) 1995 The Genetical Society of Great Britain, Heredity, 74, 4. 
We also recorded the presence of a small number of invertebrate herbivores and other plant visitors at many plant populations. To provide a sample for identification we conducted sweep-net and whole plant faunal collections of all invertebrates found on plants at Oracabessa (population 32, Fig. 3). The samples were preserved in 70 per cent ethanol and returned to the laboratory for identification.

\section{Genetic basis of variation for cyanogenesis}

To determine whether variation for cyanogenesis has a genetic basis, we exploited a variable population (population A2 in Shore \& Obrist, 1992) from which open-pollinated seed of individual plants had been sampled in January 1989 (by J.S.S.), and for which plants were growing in the greenhouse. We selfed 18 plants and grew an average of 53 progeny (range 14-90) per selfed family in a randomized design in the greenhouse. Plants were tested for cyanogenesis after flowering had commenced. Between-family variance for OD provides evidence that there is genetic variation for the trait. From this population, we also selfed and reciprocally crossed two plants that were high vs. low in cyanogenesis to test for maternal effects and the direction of dominance of the traits.

All statistical analyses were carried out using sAS (1988). Unbalanced ANOVAs were carried out using PROC GLM (SAS, 1988). ANOVAS for all OD readings were performed on log transformed data in order to make the variances homogeneous because there was a correlation between mean and variance for untransformed data. For natural plant populations it was also necessary to add 0.019 to ODs because, on occasion, small negative $O D$ readings occurred, probably the result of slight variation in the size of picrate papers and the amount of picrate in the papers used for the cyanogenesis assays.

\section{Results}

\section{Genetic basis of variation for cyanogenesis}

Earlier work (Spencer et al., 1985; Olafsdottir et al., 1990) suggested the possibility that there was variation for cyanogenesis in T. ulmifolia. A one-way ANOVA among the progeny from eighteen selfed families derived from population A2 of Shore \& Obrist (1992) was performed and the variation partitioned into within- vs. between-family sources. Between-family variance accounted for 80.6 per cent of the phenotypic variance in cyanogenesis $\left(F_{17,936}=218 ; P<0.001\right)$. This strongly suggests that there is a genetic basis to the variation (although maternal effects on cyanogenesis cannot be ruled out) and shows that considerable variation can occur within a single population. We plot frequency distributions of cyanogenesis for four contrasting selfed families in Fig. 1. Marked differences in mean cyanogenesis levels and in the distribution of variance within families are readily apparent.

As an indication of the quantitative nature of cyanogenesis, we plot the progeny mean cyanogenesis (OD) of all 18 selfed families against their ordered rank (Fig. 2). The continuous nature of the variation is clear. We have continued to exploit this variable population and have derived additional selfed lines from these progeny and have made numerous replicate cuttings of acyanogenic and cyanogenic plants for other work. These plants have maintained their high or low cyanogenic status in the greenhouse for over 5 years. In addition, we have plants which have been growing in the greenhouse since 1989 derived from populations 25 and 30 (numbers refer to Table 2 and/or Fig. 3 ) which have always been extremely cyanogenic and adult plants of population 11 which have retained their low levels of cyanogenesis (although see below).

We carried out a reciprocal cross of two plants from population A2 (and have selfed these plants to produce selfed parental lines) and analysed progeny cyanogenesis levels using the more precise methods of Lambert et al. (1975). The selfed parental lines differ markedly in cyanogenesis producing $2.5 \pm 2.9$ vs. $244 \pm 162 \mu \mathrm{g} \mathrm{HCN} / \mathrm{g}$ dry leaf tissue (mean $\pm \mathrm{SD}$ ), for the low vs. the highly cyanogenic lines, respectively (Table 1). Progeny from the reciprocal crosses did not differ significantly from one another, but did differ significantly in cyanogenesis from either parent (Table 1). These data provide no evidence for maternal effects for this cross and indicate that the inheritance of cyanogenesis is roughly additive, although there is evidence for dominance in the direction of high cyanogenesis (when measured on a log scale) as the crossed progeny means are larger than the mid-parent value. Taken together, all of these data demonstate that there is a genetic basis to variation for cyanogenesis in T. ulmifolia.

\section{Phenotypic frequency distributions of cyanogenesis}

The location, elevation and mean annual precipitation, as well as the number of plants sampled (adults and seedlings, where available) and the mean cyanogenesis levels (OD units) for field-sampled plant populations are provided in Table 2 . Figure 3 provides a map of the cyanogenesis phenotype frequencies for each fieldsampled population of adult plants. Although cyanogenesis in this species is quantitative (Fig. 2) the data for each population have been categorized into 


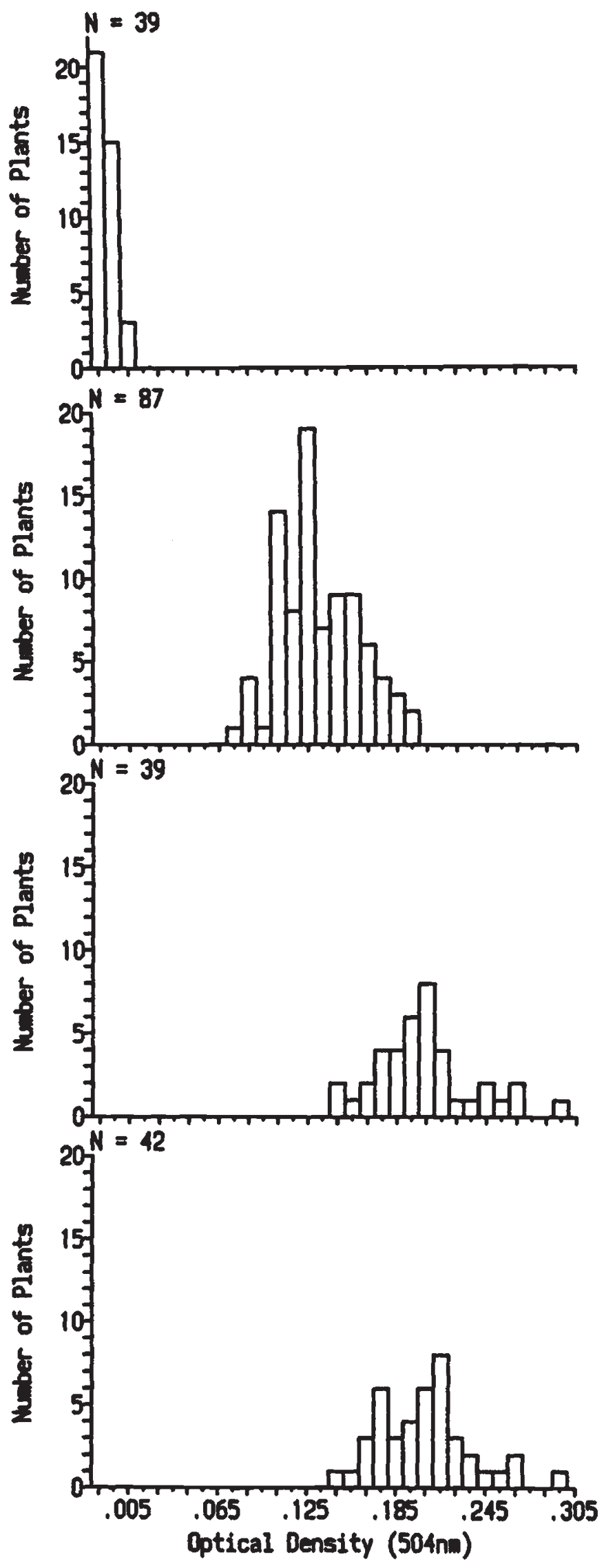

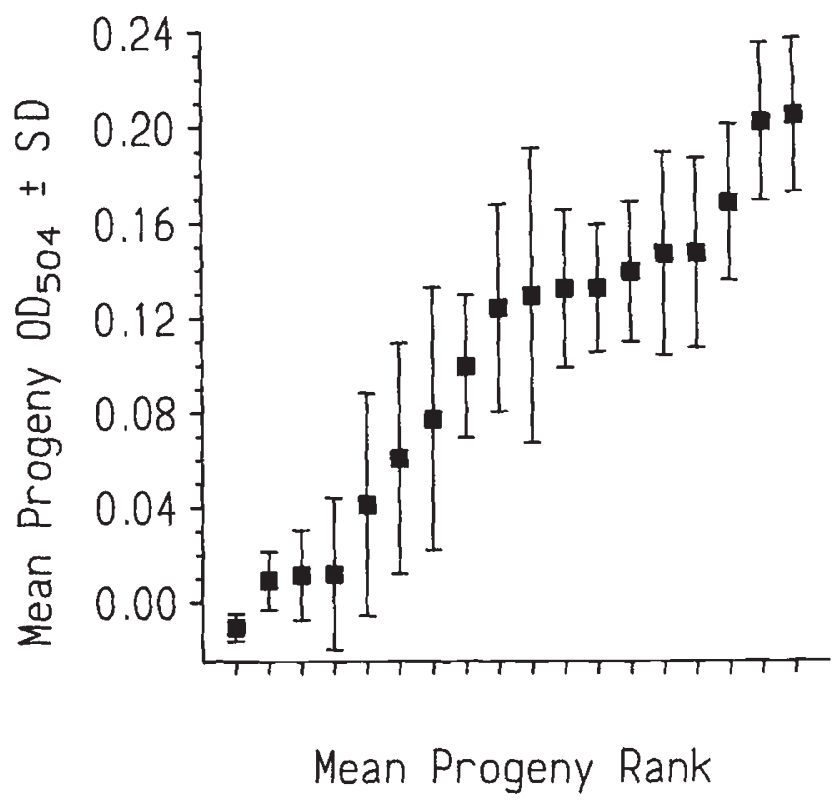

Fig. 2 Plot of mean cyanogenesis level (OD) of selfed progeny against rank of progeny mean for 18 selfed families of Turnera ulmifolia.

five classes (the 0 class is unshaded, while increasing cyanogenesis is indicated by increasing shading density in classes 1 through 4) for presentation.

The map (Fig. 3) demonstrates wide variation for cyanogenesis on the island of Jamaica. Some populations have a high frequency of plants that are highly cyanogenic (e.g. populations $25,26,30$ ), while other populations contain plants that apparently do not liberate $\mathrm{HCN}$ (e.g. population 20). There appears to be an area of high cyanogenesis in the south central portion of the island while the north coast tends to have populations with lower frequencies as well as less intense cyanogenesis reactions. These phenotypic distributions indicate that there is marked geographical variation for cyanogenesis among populations of $T$. ulmifolia on Jamaica.

There also appears to be appreciable variation on a finer spatial scale. In the vicinity of Kinloss (population 14), we sampled plants at six stations approximately every $2 \mathrm{~km}$ along an elevational gradient of $304.8 \mathrm{~m}$. Analysis of variance revealed significant differences among sites with more frequent and more strongly cyanogenic plants occurring at higher elevations $\left(F_{5,84}=8.84, P<0.001 ;\right.$ Fig. 4$)$.

Fig. 1 Frequency distributions of cyanogenesis (OD) for four selfed families of Turnera ulmifolia from population A2 illustrating contrasting cyanogenesis levels. 


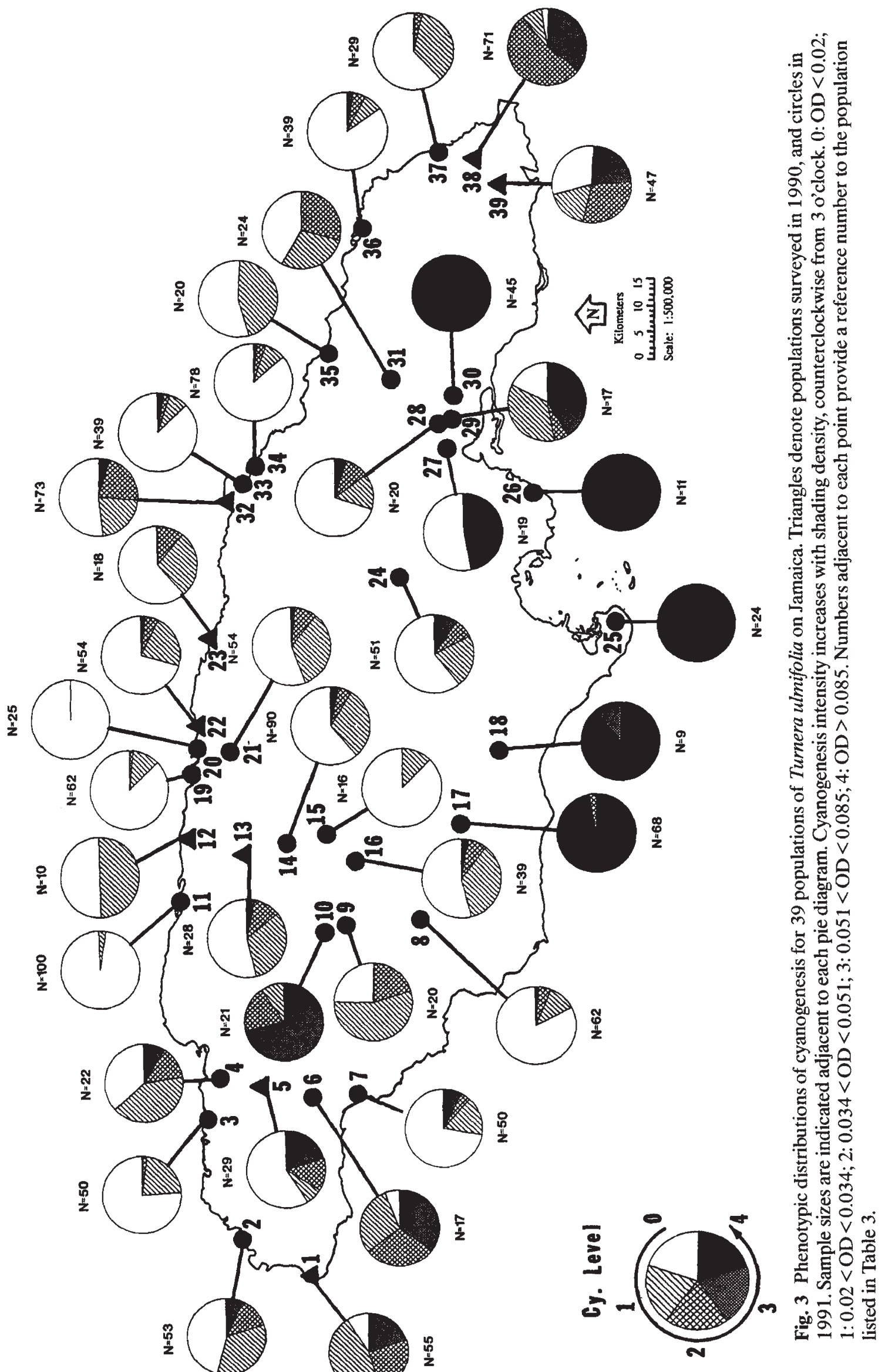


Table 1 Mean cyanogenesis levels (expressed as natural $\log (\mu \mathrm{g} \mathrm{HCN} / \mathrm{gram}$ dry leaf tissue $))$ for selfed progeny and the progeny from the reciprocal cross of two parental plants from Turnera ulmifolia population A2, differing markedly in their cyanogenesis levels

\begin{tabular}{lcc}
\hline Cross & No. of progeny & Mean (SD) \\
\hline Low HCN selfed & 15 & $0.90(0.89)^{\mathrm{a}}$ \\
Low HCN $\times$ High HCN & 17 & $3.75(0.95)^{\mathrm{b}}$ \\
High HCN $\times$ Low HCN & 17 & $3.95(0.80)^{\mathrm{b}}$ \\
High HCN selfed & 17 & $5.25(0.76)^{\mathrm{c}}$ \\
\hline
\end{tabular}

High $\mathrm{HCN}=$ highly cyanogenic parent, Low $\mathrm{HCN}=$ low HCN parent.

Means with different letters are significantly different $(P<0.05)$ using Scheffe's test.

One-way ANOvA among families gave $F_{3,62}=72.4, P<0.001$.

\section{Cyanogenesis in seedlings vs. adults}

We were able to identify seedlings in 16 natural populations of $T$. ulmifolia that could be assayed for cyanogenesis. Our first seedling vs. adult comparison was performed in one of the larger populations sampled, at Falmouth (population 11), where we encountered a large number of seedlings. From this population we randomly sampled 100 adult plants and then sampled the seedling nearest to the base of each adult. Interestingly, seedlings had significantly higher levels of cyanogenesis than adults (Fig. 5), and this was readily apparent to the naked eye based upon picrate paper colour change. We sampled additional populations in an effort to replicate this result. Our data and analysis of the 12 populations for which we could identify and sample five or more seedlings (Fig. 6 and Table 3) show that there are significant effects between populations and between life history stages (adults vs. seedlings). In addition, there is an interesting interaction between population and life history stage. Populations with adult plants exhibiting lower levels of cyanogenesis tend to have seedlings that have higher levels of cyanogenesis, while populations of adult plants high in cyanogenesis (e.g. population 31 ) tend to have seedlings with comparable levels of cyanogenesis (Fig. 6 and see Table 2). Significant differences between seedling and adult plant cyanogenesis were also recorded along the Kinloss transect (population 14, Fig. 6).

\section{Chemical variation for cyanogenesis}

To explore the chemical nature of variation in cyanogenesis we added exogenous cyanogenic glycoside to plants from three populations $(11,21$ and 33). Previous work had revealed that populations of T. ulmifolia, as well as apparently acyanogenic species in the genus, all possess the enzymes necessary to hydrolyse cyanogenic glycosides (Shore \& Obrist, 1992). Our data and analysis reveal a marked increase in cyanogenesis when exogenous glycoside is added to crushed leaves (Tables 4 and 5). The treatment term in the ANOva (Table 5) has by far the largest mean square indicating that it is the most important source of variation. There are small but significant differences among the three populations and a significant population by treatment effect. These are likely to be the result of population differences in mean cyanogenesis as well as similar amounts of glycoside additions swamping out the effects of endogenous glycoside levels.

\section{Identification of potential selective agents}

We have yet to measure directly whether natural selection is acting on variation for cyanogenesis. We have, however, made preliminary surveys of potential abiotic and biotic selective agents. There is a significant negative correlation between dry season rainfall (November through April) and cyanogenesis for the 39 natural populations surveyed, but no correlation with wet season rainfall or elevation of the population (Table 6).

A small number of herbivorous insects of various orders have been found on the plants, and some of these were observed to consume plant tissue. Interestingly, two species of snails (Cepolis sp. and Urocoptis sp.; Jacobson, 1950) have been observed on plants in four populations $(11,19,28,32)$. A number of plant tissues were found to be used preferentially by a small number of herbivorous insects including stemand fruit-boring lepidopterans, a dipteran leaf miner and guilds of leaf- and stem-piercing (aphids, fulgoroids and various hemipterans) and leaf-chewing (chrysomelids, acridids and two lepidopterans) insects. The most commonly encountered herbivores included two unidentified species of chrysomelids and a number of species of aphids. Potentially the most damaging of the commonly encountered herbivores, in terms of tissue loss per unit time, are the larvae of the nymphalid butterfly, Euptoieta hegesia (pers. obs.).

\section{Discussion}

Our demonstration of wide variation for cyanogenesis among populations of $T$. ulmifolia on the island of Jamaica (Fig. 3) is the first example of extensive genetic variation for this chemical trait in natural populations of a tropical species. The nature of the variation appears to differ from that of the well-studied temperate species, Lotus corniculatus and Trifolium repens, as it is continuous and probably under poly- 


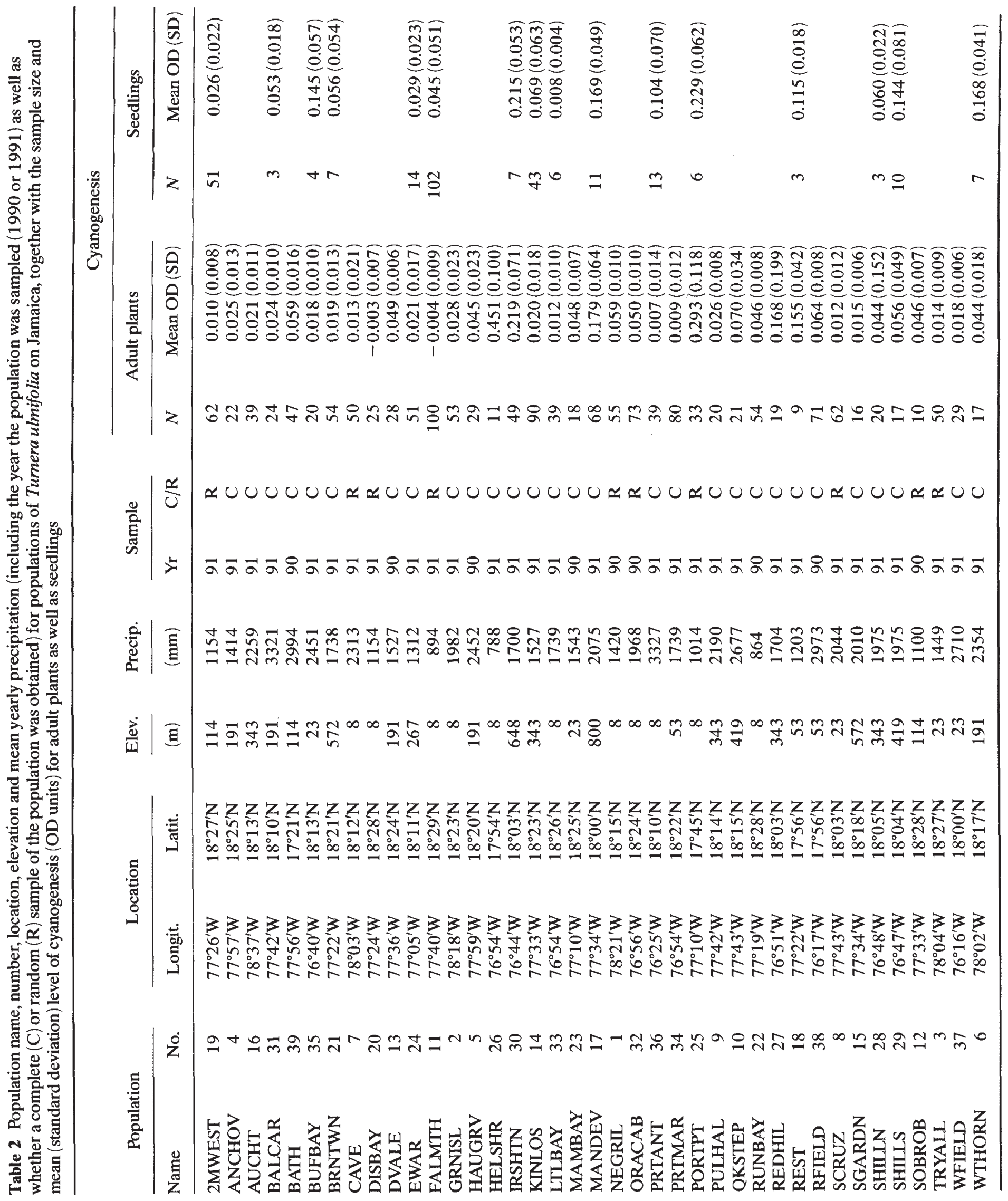




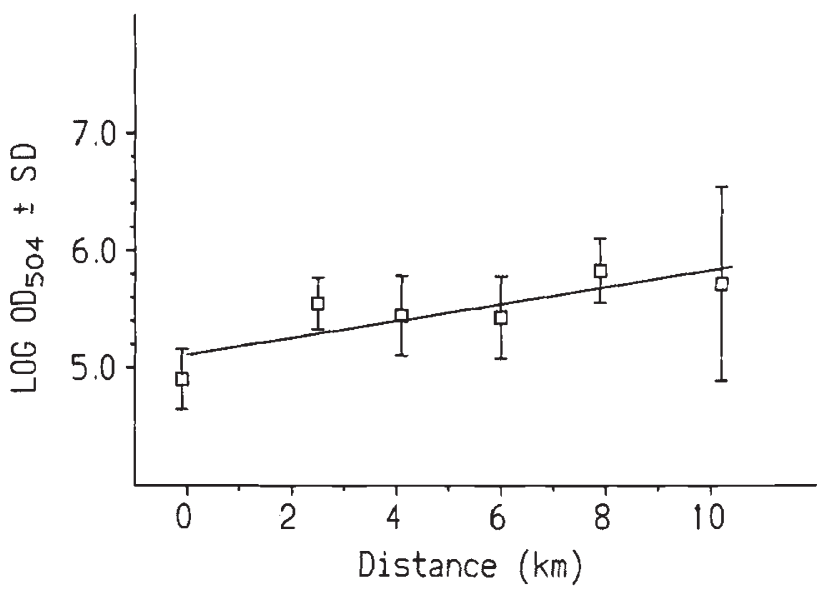

Fig. 4 Mean cyanogenesis of adult Turnera ulmifolia along a $10.3 \mathrm{~km}$ transect spanning an elevational gradient of $305 \mathrm{~m}$, near the town of Kinloss (population 14).

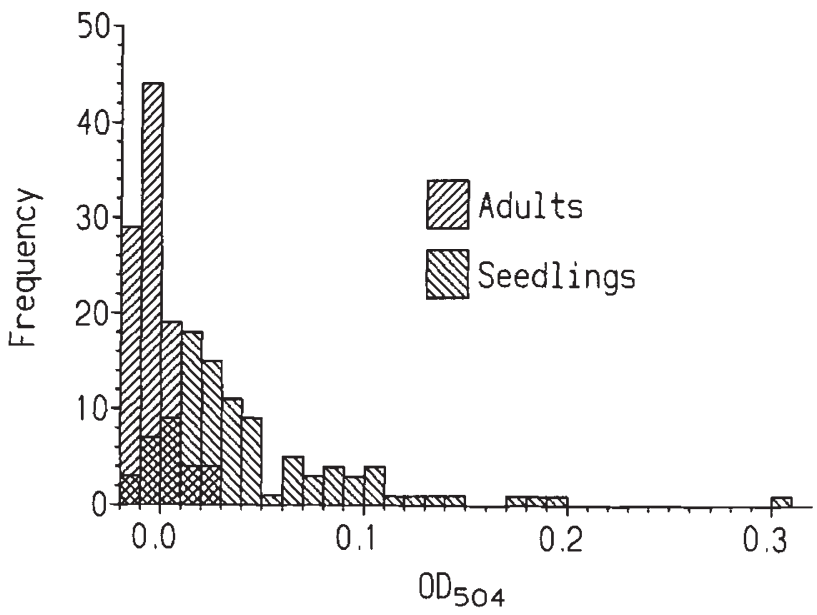

Fig. 5 Frequency distribution of cyanogenesis (OD) for 100 adults and 102 seedlings of Turnera ulmifolia from a random sample at Falmouth (population 11).

genic control. The variation provides an opportunity to determine whether selection pressures similar to those observed for $L$. corniculatus and $T$. repens might account for the geographical distribution of cyanogenesis observed on the island.

Broad-scale geographical variation occurs on Jamaica (Fig. 3), with highly cyanogenic populations in the south central region, weakly or mostly acyanogenic populations occurring along the north coast and populations showing intermediate levels generally increasing in cyanogenesis, both in frequency and $\mathrm{HCN}$ release, from north to south. Variation also occurs over relatively short distances, as at Kinloss (population 14), where we found significant differences among six sites along an elevational gradient (Fig. 4). We do not imply

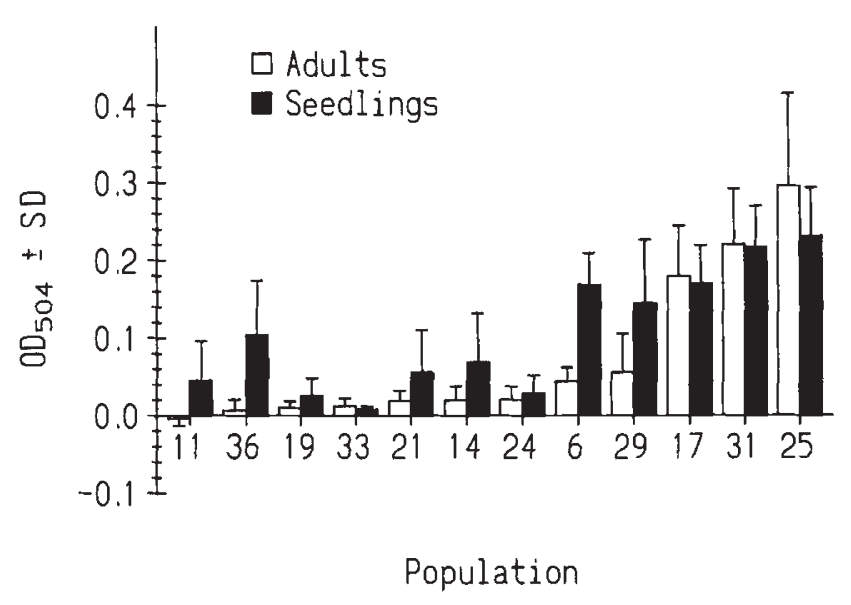

Fig. 6 Mean cyanogenesis (OD) for twelve populations of Turnera ulmifolia for which adults and progeny could both be assayed. Populations are ranked from low to high adult cyanogenesis. Population numbers refer to locations on Fig. 3 and data in Table 2.

Table 3 Two-way ANova comparing mean cyanogenesis levels $(\log (\mathrm{OD}))$ of adult plants vs. seedlings for 12 populations of Tumera ulmifolia

\begin{tabular}{lrrr}
\hline Source & d.f. & \multicolumn{1}{c}{ MS } & \multicolumn{1}{c}{$F$} \\
\hline Population & 11 & 29.9 & $6.36^{* *}$ \\
Life stage & 1 & 26.4 & $8.80^{* *}$ \\
Pop $\times$ Stage & 11 & 4.7 & $18.12^{* * *}$ \\
Error & 848 & 0.3 & \\
\hline
\end{tabular}

${ }^{* *} P<0.01,{ }^{* * *} P<0.001$.

Population source was considered a random effect.

Table 4 Effect of exogenous glycoside addition on cyanogenesis (OD units) for three populations of Turnera ulmifolia showing low levels of cyanogenesis

\begin{tabular}{lcrr}
\hline & & \multicolumn{2}{c}{ Mean OD (SD) } \\
\cline { 3 - 4 } Population & $N$ & \multicolumn{1}{c}{ Control } & + Glycoside \\
\hline FALMTH & 10 & $-0.009(0.006)$ & $0.261(0.040)$ \\
LTLBAY & 16 & $0.009(0.006)$ & $0.235(0.048)$ \\
BRNTWN & 10 & $0.015(0.014)$ & $0.259(0.051)$ \\
\hline
\end{tabular}

that increasing altitude is a cause of variation in cyanogenesis, but simply that spatial variation for cyanogenesis occurs on more local levels, perhaps the result of limited gene flow within substructured populations. Our data on phenotypic distributions (Fig. 3 and Table 2) certainly show that high-cyanide populations occur at sea-level (population 25, mean OD 0.293 ) as well as at the highest elevations sampled (populations 17 and 30,800 and $648 \mathrm{~m}$ with mean 
Table 5 ANOVA for differences in mean cyanogenesis $(\log (\mathrm{OD}))$ of adult plants for three populations of Turnera ulmifolia following addition of exogenous glycoside

\begin{tabular}{|c|c|c|c|}
\hline Source & d.f. & MS & $F$ \\
\hline Population & 2 & 2.4 & $27.3^{* * *}$ \\
\hline Treatment & 1 & 117.0 & $936.5^{* * *}$ \\
\hline Pop $\times$ Treatment & 2 & 2.9 & $23.3^{* * *}$ \\
\hline Plant (Pop) & 33 & 0.1 & 0.7 \\
\hline Error & 33 & 0.1 & \\
\hline
\end{tabular}

*** $P<0.001$.

Plant(pop) indicates a term for plants nested within populations.

Table 6 Correlations between mean cyanogenesis level and selected abiotic factors for 39 populations of Turnera ulmifolia on Jamaica

\begin{tabular}{lcc}
\hline Variable & Correlation & $P$ \\
\hline Elevation & 0.17 & 0.29 \\
Wet season rainfall & -0.12 & 0.47 \\
Dry season rainfall & -0.42 & 0.008 \\
Total rainfall & -0.30 & 0.07 \\
\hline
\end{tabular}

OD's of 0.179 and 0.219 , respectively). Conversely, some high-elevation populations exhibit low levels of cyanogenesis (population $21,572 \mathrm{~m}$, OD 0.019 ; population $15,572 \mathrm{~m}, \mathrm{OD} 0.015$ ) as do some sea-level populations (e.g. population 20, OD -0.003). Elevation does not seem to be an important factor in determining the distribution of cyanogenesis in this tropical species, unlike $T$. repens. For this temperate species, elevation is important since it determines the distribution of selective herbivores (Crawford-Sidebotham, 1972a) and since the cool temperatures of high elevations are reported to select directly against cyanogenesis as a result of frost damage (Daday, 1954a,b, 1965; Dirzo \& Harper, 1982b; Blaise et al., 1991).

Exploratory analyses revealed a significant negative correlation between dry season rainfall and cyanogenesis that accounts for 17.6 per cent of the variation in the data (Table 6). Despite this finding, we note that the populations that are the most cyanogenic $(26$, mean $\mathrm{OD}=0.451)$ and the least cyanogenic $(11$, mean $\mathrm{OD}=-0.004)$ are widely separated yet both experience very similar dry season rainfall (both at $8 \mathrm{~m}$ elevation, with 3 per cent of average yearly rainfall in March). Populations occurring at higher elevations (e.g. 30 , mean $\mathrm{OD}=0.219,648 \mathrm{~m}$ elev., and 21 , mean $\mathrm{OD}=0.019,572 \mathrm{~m}$ elev.) and those which are in close proximity but at disparate elevations (17, mean $\mathrm{OD}=0.179,800 \mathrm{~m}$ elev., and 8 , mean $\mathrm{OD}=0.012$, $23 \mathrm{~m}$ elev., $18 \mathrm{~km}$ between populations) also experience similar dry season precipitation regimes. The highly cyanogenic populations of the south central lowlands are located, to varying extent, in a winter/dry season rainshadow because of the location of the Blue Mountains in the northeast and of the northeast tropical tradewinds. The location of these strongly cyanogenic (and the high frequency of cyanogenic plants in these) populations is probably responsible for the correlation between cyanogenesis and dry season rainfall and so the correlation above may be spurious. If dry season rainfall is a weak selective factor it is unclear whether it is responsible for determining the distribution of some herbivore or whether it might act directly in some way. It is interesting to note that some studies of $T$. repens and $L$. corniculatus have shown that cyanogenic genotypes are selected against by moisture stress (Foulds \& Grime, 1972; Abbott, 1977; but see Foulds, 1977 and Ennos, 1981). If moisture stress is a selective factor for T. ulmifolia, then it would appear to act in exactly the opposite direction.

Genetic studies of continuous variation in a population of T. ulmifolia have shown that more than 80 per cent of the phenotypic variance in cyanogenesis occurs between families and there is no evidence for maternal effects (Table 1, Fig. 2). We are currently conducting genetic studies of a number of Jamaican populations to obtain further estimates of heritability. Since plants of T. ulmifolia from Jamaica are hexaploid (Barrett \& Shore, 1987) and we have demonstrated that cyanogenesis probably depends on the quantity of cyanogenic glycosides present (Table 4), a working hypothesis is that dosage effects resulting from variation at triplicate gene loci is responsible for the quantitative nature of the trait. A second possibility to account for the quantitative nature of the variation arises from a suggestion by Spencer (1988) that the production of cyclopentenoid cyanogenic glycosides (i.e. those found in species within the Turneraceae and allied families in the Passiflorales and Violales) are the result of a complex pathway involving many genes. Indeed, some details of the biochemical pathway leading to the synthesis of the cyclopentenoid cyanogenic glycoside, deidaclin, from the unusual amino acid, 2-cyclopentenylglycine, have been determined for $T$. ulmifolia (Spencer \& Seigler, 1980; Tober \& Conn, $1985)$. Variation in a number of genes contributing to the biosynthetic pathway might account for the continuous nature of variation for the trait.

To address whether cyanogenesis in T. ulmifolia is an antiherbivore defence will require appropriate field experiments (e.g. see Jones, 1962, 1966; Ennos, 1981; Dirzo \& Harper, 1982a,b; Horrill \& Richards, 1986). Cyanogenesis is reported to be a general inhibitor of feeding to infrequent or opportunistic herbivores (Dritschilo et al., 1979; Compton \& Jones, 1985; 
Nahrstedt, 1985; but see also Hruska, 1988) and Woodhead \& Bernays (1978) found that $\mathrm{HCN}$ release, not the presence of cyanogenic glycosides, is responsible for the unpalatability of Sorghum bicolor to Locusta migratoria. The herbivores found on plants of T. ulmifolia were frequently recorded from a wide variety of populations on the island, although more detailed work is required to map out the distribution of herbivores for a number of populations throughout the year. Importantly, the damage caused by these herbivores is distinct and easily recognized. The feeding methods of some herbivores (e.g. aphids (Jones, 1983) and possibly small chrysomelids) may minimize their direct contact with $\mathrm{HCN}$ release and, therefore, they may be unlikely selective agents for cyanogenesis. On the other hand, single (but often two or three) larvae of the relatively large lepidopteran Euptoieta hegesia are easily capable of defoliating average-sized plants. We are currently investigating the scope of the interaction between this herbivore and the cyanogenic variation of T. ulmifolia (Schappert \& Shore, unpubl. studies).

A few authors have reported that seedlings or immature tissue of plants in species which exhibit polymorphism have high cyanogenesis levels (Jones, 1962; Eck et al., 1975; Cooper-Driver \& Swain, 1976; Shore \& Obrist, 1992) and many have suggested that cyanogenesis may be of particular defensive benefit to seedlings or prereproductive plants (e.g. Jones, 1962, 1971; Crawford-Sidebotham, 1972b (Lotus corniculatus); Dritschilo et al., 1979; Kakes, 1989, 1990 (Trifolium repens); Cooper-Driver \& Swain, 1976 (Pteridium aquilinum)). In this paper we have also reported that seedlings in predominately acyanogenic adult plant populations of $T$. ulmifolia possess high levels of cyanogenic glycosides. There are at least two hypotheses to account for the higher levels of cyanogenesis in seedlings vs. adult plants: (1) there could be selection against cyanogenesis in the populations studied (i.e. seedlings that are more cyanogenic do not survive to become adults in these populations) or, (2) there is developmental variation in the expression of cyanogenesis, with seedlings expressing higher levels of cyanogenesis than adults. We are currently growing plants from a number of populations and assaying them for cyanogenesis at known times, to test the second hypothesis. Preliminary data reveal that emergent seedlings from predominantly acyanogenic populations have high cyanogenesis levels and exhibit reduced cyanogenesis as they age, rapidly losing their $\mathrm{HCN}$ potential in the first three months of growth. Plants from highly cyanogenic populations appear to retain their highly cyanogenic status throughout their life history (Schappert \& Shore, unpublished data).

\section{Acknowledgements}

We wish to thank Oron Anter, Angela Baker, Mark DeBoer, Gus Lagos, Susan Mitchell, and Pat Schappert for technical assistance in the laboratory and field, Dr. J. D. Woodley and the staff at the Discovery Bay Marine Laboratory for logistical aid, and Laurence Packer and an anonymous reviewer for useful comments on the manuscript. The study was funded by a Natural Sciences and Engineering Research Council operating grant to J. S. Shore.

\section{References}

ABBOTT, R. J. 1977. A quantitative association between soil moisture content and the frequency of the cyanogenic form of Lotus corniculatus L. at Birsay, Orkney. Heredity, 38, 397-400.

ANGSEESING, J. P. A. AND ANGSEESING, w. J. 1973. Field observations of the cyanogenesis polymorphism in Trifolium repens. Heredity, 31, 276-282.

BARRETT, S. C. H. AND SHORE, J. S. 1987. Variation and evolution of breeding systems in the Turnera ulmifolia L. complex (Turneraceae). Evolution, 41, 340-354.

BELAOUSSOFF, S. AND SHORE, J. S. 1995. Floral correlates and fitness consequences of mating system variation in Turnera ulmifolia. Evolution, (in press).

BISHOP, J. A. AND KORN, M. E. 1969. Natural selection and cyanogenesis in white clover, Trifolium repens. Heredity, 24, 423-430.

BLAISE, S., CARTIER, D. AND REYNAUD, J. 1991. Evolution and differentiation of Lotus corniculatus/Lotus alpinus populations from French south-western Alps. I. Morphologic and cyanogenic variations. Evol. Trends Plants, 5, 137-148.

BRIGGS, M. A. AND SCHULTZ, J. C. 1990. Chemical defence production in Lotus corniculatus L. I. Trade-offs among growth, reproduction and defence. Oecologia, 83, 32-37.

BRINKER, A. M. AND SEIGLER, D. S. 1989. Methods for the detection and quantitative determination of cyanide in plant materials. Phytochem. Bull., 21, 24-31.

BURGESS, R. S. L. AND ENNOS, R. A. 1987. Selective grazing of acyanogenic white clover: Variation in behaviour among populations of the slug Deroceras reticulatum. Oecologia, 73, 432-435.

COMPTON, S. G. AND JONES, D. A. 1985. An investigation of the responses of herbivores to cyanogenesis in Lotus corniculatus L. Biol. J. Linn. Soc., 26, 21-38.

CONN, E. E. 1979. Cyanide and cyanogenic glycosides. In: Rosenthal, G. A. and Janzen, D. H. (eds) Herbivores: Their Interaction with Secondary Plant Metabolites, pp. 387-412. Academic Press, New York.

COOPER-DRIVER, G. A. AND SWAIN, T. 1976. Cyanogenic polymorphism in bracken in relation to herbivore predation. Nature, 260, 604.

COOPER-DRIVER, G., FINCH, S., SWAIN, T. AND BERNAYS, E. 1977. Seasonal variation in secondary plant compounds in rela- 
tion to the palatability of Pteridium aquilinum. Biochem. Syst. Ecol., 5, 177-183.

CRAWFORD-SIDEBOTHAM, T. J. 1972a. The influence of weather upon the activity of slugs. Oecologia, 9, 141-154.

CRAWFORD-SIDEBOTHAM, T. J. $1972 \mathrm{~b}$. The role of slugs and snails in the maintenance of the cyanogenesis polymorphisms of Lotus corniculatus and Trifolium repens. Heredity, 28, 405-411.

DADAY, H. 1954a. Gene frequencies in wild populations of Trifolium repens L. I. Distribution by latitude. Heredity, $\mathbf{8}$, 61-78.

DADAY, H. 1954b. Gene frequencies in wild populations of Trifolium repens L. II. Distribution by altitude. Heredity, $\mathbf{8}$, 377-384.

DADAY, H. 1965. Gene frequencies in wild populations of Trifolium repens L. IV. Mechanism of natural selection. Heredity, 20, 355-365.

DAwSON, C. D. R. 1941. Tetrasomic inheritance in Lotus corniculatus L. J. Genet, 42, 49-72.

DIRZO, R. AND HARPER, J. L. 1982a. Experimental studies on slug-plant interactions III. Differences in the acceptability of individual plants of Trifolium repens to slugs and snails. J. Ecol, , 70, 101-117.

DIRZO, R. AND HARPER, J. L. 1982b. Experimental studies on slug-plant interactions IV. The performance of cyanogenic and acyanogenic morphs of Trifolium repens in the field. J. Ecol., 70, 119-138.

DRITSCHILO, W., KRUMMEL, J., NAFUS, D. AND PIMENTEL, D. 1979. Herbivorous insects colonising cyanogenic and acyanogenic Trifolium repens. Heredity, 42, 49-56.

ECK, H. V., GILMORE, E. C., FERGUSON, D. B. AND WILSON, G. C. 1975. Heritability of nitrate reductase and cyanide levels in seedlings of grain sorghum cultivars. Crop Sci., 15, 421-424.

ELLIS, W. M., KEYMER, R. J. AND JONES, D. A. 1977a. The effect of temperature on the polymorphism of cyanogenesis in Lotus corniculatus L. Heredity, 38, 339-347.

ELLIS, W. M., KEYMER, R. J. AND JONES, D. A. 1977 b. On the polymorphism of cyanogenesis in Lotus corniculatus L. VIII. Ecological studies in Anglesey. Heredity, 39, 45-65.

ELLIS, W. M., KEYMER, R. J. AND JONES, D. A. 1977c. The defensive function of cyanogenesis in natural populations. Experientia, 33, 309-311.

ENNOS, R. A. 1981. Detection of selection in populations of white clover (Trifolium repens L.). Biol. J. Linn. Soc., 15, 75-82.

Foulds, w. 1977. The physiological response to moisture supply of cyanogenic and acyanogenic phenotypes of Trifolium repens L. and Lotus corniculatus L. Heredity, 39, 219-234.

FOULDS, W. AND GRIME, J. P. 1972. The influence of soil moisture on the frequency of cyanogenic plants in populations of Trifolium repens L. and Lotus corniculatus L. Heredity, 28, 143-146.

Foulds, w. AND YoUNG, L. 1977. Effect of frosting, moisture stress and potassium cyanide on the metabolism of cyanogenic and acyanogenic phenotypes of Lotus corniculatus L. and Trifolium repens L. Heredity, 38, 19-24.

HORRILL, J. C. AND RICHARDS, A. J. 1986. Differential grazing by the mollusc Arion hortensis Fér. on cyanogenic and acyanogenic seedlings of the white clover, Trifolium repens L. Heredity, 56, 277-281.

HOSEL, W. AND CONN, E. E. 1982. The aglycone specificity of $\beta$-glycosidases. Trends Biochem. Sci., June 1982, 219-221.

HRUSKA, A. J. 1988. Cyanogenic glucosides as defence compounds. A review of the evidence. J. Chem. Ecol., 14, 2213-2217.

HUGHES, M. A. 1981. The genetic control of plant cyanogenesis. In: Vennesland, B., Conn, E. E., Knowles, C. J., Westly, J. and Wissing, F. (eds) Cyanide in Biology, pp. 495-508. Academic Press, London.

HUGHES, M. A. 1991. The cyanogenic polymorphism in Trifolium repens $\mathrm{L}$. (white clover). Heredity, 66, 105-115.

HUGHES, M. A., STIRLING, J. D. AND COllinge, D. B. 1984. The inheritance of cyanoglucoside content in Trifolium repens L. Biochem. Genet., 22, 139-151.

JACOBSON, M. K. 1950. The land snails of Jamaica. Natural History Notes of the Natural History Soc. of Jamaica, 41, 89-93 and 42, 113-114.

JIS, 1967. The Handbook of Jamaica for 1967, pp. 46-72. Jamaica Information Service, Kingston, Jamaica, W. I.

JoNES, C. G. 1983. Phytochemical variation, colonisation, and insect communities: the case of Bracken Fern (Pteridium aquilinum). In: Denno, R. F. and McClure, M. S. (eds) Variable Plants and Herbivores in Natural and Managed Systems, pp. 513-558. Academic Press, New York.

JONES, D. A. 1962. Selective eating of the acyanogenic form of the plant Lotus corniculatus L. by various animals. Nature, 193, 1109-1110.

JONES, D. A. 1966. On the polymorphism of cyanogenesis in Lotus corniculatus. I. Selection by animals. Can. J. Genet. Cytol., 8, 556-567.

JONES, D. A. 1971. Chemical defense mechanisms and genetic polymorphism. Science, 173, 945.

JONES, D. A. 1973. Co-evolution and cyanogenesis. In: Heywood, V. H. (ed.) Taxonomy and Ecology, pp. 213-242. Academic Press, London.

JONES, D. A. 1977 . On the polymorphism of cyanogenesis in Lotus corniculatus L. VII. The distribution of the cyanogenic form in Western Europe. Heredity, 39, 27-44.

JONES, D. A. 1981. Cyanide and coevolution. In: Vennesland, B., Conn, E. E., Knowles, C. J., Westley, J. and Wissing, F. (eds) Cyanide in Biology, pp. 509-516. Academic Press, London.

JONES. D. A. 1988. Cyanogenesis in animal-plant interactions. In: Evered, D. and Harnett, S. (eds) Cyanide Compounds in Biology, pp. 151-176. Wiley \& Sons, Chichester, U.K.

JONES, D. A., KEYMER, R. J. AND ELLIS, W. M. 1978. Cyanogenesis in plants and animal feeding. In: Harborne, J. B. (ed.) Biochemical Aspects of Plant and Animal Coevolution, pp. 21-34. Academic Press, London.

KAKES, P. 1989. An analysis of the costs and benefits of the cyanogenic system in Trifolium repens L. Theor. Appl. Gen., 77, 111-118.

KAKES, P. 1990. Properties and functions of the cyanogenic system in higher plants. Euphytica, 48, 25-43.

LAMBERT, J. L., RAMASAMY, J. AND PAUKSTELIS, J. V. 1975. Stable 
reagents for the colorimetric determination of cyanide by modified König reactions. Analyt. Chem., 47, 916-918.

NAHRSTEDT, A. 1985. Cyanogenic compounds as protecting agents for organisms. Plant Syst. Evol., 150, 35-47.

NASS, H. G. 1972. Cyanogenesis: its inheritance in Sorghum bicolor, Sorghum sudanense, Lotus, and Trifolium repens - a review. Crop Sci., 12, 503-506.

OLAFSDOTTIR, E. S., JAROSZEWSKI, J. W. AND ARBO, M. M. 1990. Cyanohydrin glucosides of Turneraceae. Biochem. Syst. Ecol., 18, 435-438.

Poulton, J. E. 1990. Cyanogenesis in plants. Plant Physiol., 94, 401-405.

SAS, 1988. SAS/STAT User's Guide, Release 6.03 Edition. SAS Institute, Cary, NC.

SAUPE, S. G. 1981. Cyanogenic compounds and angiosperm phylogeny. In: Young, D. A. and Seigler, D. S. (eds) Phytochemistry and Angiosperm Phylogeny, pp. 80-116. Praeger, New York.

SCHREINER, I., NAFUS, D. AND PIMENTEL, D. 1984. Effects of cyanogenesis in bracken fern (Pteridium aquilinum) on associated insects. Ecol. Entomol., 9, 69-79.

SCRIBER, J. M. 1978. Cyanogenic glycosides in Lotus corniculatus. Their effect upon growth, energy budget, and nitrogen utilisation of the Southern Armyworm, Spodoptera eridania. Oecologia, 34, 143-155.

SEIGLER, D. S. 1991. Cyanide and cyanogenic glycosides. In: Rosenthal, G. A. and Berenbaum, M. R. (eds) Herbivores: Their Interaction with Secondary Plant Metabolites, $2 E$, Vol. 1: The Chemical Participants, pp. 35-77. Academic Press, San Diego, CA.
SHORE, J. S. AND OBRIST, C. M. 1992. Variation in cyanogenesis within and among populations and species of Turnera series Canaligerae (Turneraceae). Biochem. Syst. Ecol., 20, 9-15.

SPENCER, K. C. 1988. Chemical mediation of coevolution in the Passiflora-Heliconius Interaction. In: Spencer, K. C. (ed.) Chemical Mediation of Coevolution, pp. 167-240. Academic Press, San Diego, CA.

SPENCER, K. C. AND SEIGLER, D. S. 1980. Deidaclin from Turnera ulmifolia. Phytochemistry, 19, 1863-1864.

SPENCER, K. C. AND SEIGLER, D. S. 1981. Tetraphyllin B from Turnera diffusa. Planta Medica, 43, 175-178.

SPENCER, K. C., SEIGLER, D. S. AND FRALEY, S. W. 1985. Cyanogenic glycosides of the Turneraceae. Biochem. Syst. Ecol., 13, 433-435.

TakHtajan, A. 1969. Flowering Plants: Origin and Dispersal. Oliver and Boyd, Edinburgh.

TILL, 1. 1987. Variability of expression of cyanogenesis in white clover (Trifolium repens L.). Heredity, 59, 265-271.

TOBER, I. AND CONN, E. E. 1985. Cyclopentenylglycine, a precursor of deidaclin in Turnera ulmifolia. Phytochemistry, 24, 1215-1218.

URBANSKA, K. 1982. Polymorphism of cyanogenesis in Lotus alpinus from Switzerland. I. Small-scale variability in phenotypic frequencies upon acidic silicate and carbonate. Ber. Geobot. Inst. E. T. H., Stiftung Rübel, 49, 35-55.

WOODHEAD, S. AND BERNAYS, E. A. 1978 . The chemical basis of resistance of Sorghum bicolor to attack by Locusta migratoria. Entomologia exp. appl., 24, 123-144. 